\title{
A Wine Flight of Gendered Sociology: Vignettes of (Apparent) Trivialities
}

\author{
Anna-Mari Almila ${ }^{1 *}$
}

\section{${ }^{1}$ University of Helsinki, FINLAND}

*Corresponding Author: anna-mari.almila@helsinki.fi

Citation: Almila, A.-M. (2021). A Wine Flight of Gendered Sociology: Vignettes of (Apparent) Trivialities, Journal of Cultural Analysis and Social Change, 6(2), 11. https://doi.org/10.20897/jcasc/11449

Published: December 30, 2021

\begin{abstract}
This paper discusses the genderedness of wine through a focus on seven illuminative vignettes. Academic studies about wine, women and men have approached the subject by focussing on professional wine worlds, gendered wine consumption, and more general patterns of the genderedness of wine. Here I discuss what sorts of boundaries wine builds and breaks, and what kinds of taboos and threats are connected to winegender relations. What emerges from my approach is a cultural gendered sociology of wine, inspired by Mary Douglas. The boundaries discussed are more than symbolic, they are often deeply embodied, too. Yet the symbolic level is where meaning of wine-gender relations is constructed, recognised, and acted upon, in terms of powerful taboos to do with sexuality, gendered bodies, human reproduction, and gender boundaries. I argue that a deep understanding of why and how wine continues to be gendered cannot be gained through only researching forms of industry and social discrimination, and strategies of survival and success. To explain the enormous power of wine and gender and wine's genderedness, a deep cultural sociology is needed.
\end{abstract}

Keywords: wine, gender, gender boundaries, Mary Douglas, women

\section{GETTING YOUR TASTE BUDS READY}

The problem of writing about wine and gender is the vastness of the subject and material to examine on the one hand, and the limitedness of existing information on the other. Which elements of the massive world(s) of wine are not gendered, historically and today, and from one geographical and cultural context to another? How to write about these, such that the complex and varied factors would be richly presented and adequately represented? I aim to understand wine-gender relations: the fact that wine and gender seem to be fundamentally intertwined wherever and whenever wine is made or drunk. I have chosen to focus on seven illuminative vignettes, regarding some, but certainly not all, gendered characteristics of wine. I highlight examples that may seem fairly trivial at first glance, but eventually come to reveal how it is precisely such trivial, seemingly harmless details that in fact illustrate how wine marks, recreates, strengthens, challenges, accommodates, and adjusts gender boundaries. ${ }^{1}$

A better-known expression for such an approach is 'snapshots'. Simmel (2012: 274) used the expression 'Momentbilder' [momentary images] in a collection of three experimental philosophical essays, a term that was later translated into 'snapshots'. Simmel (2012), writes Smith (1989: 24), 'was never afraid to attempt to extract universally valid principles from the most insignificant phenomena'. Although I do not seek universally valid principles, nevertheless I am inspired by Simmel's (2012) ideas: 'Amidst the historical and cultural variability of the contents of social life[,] formal sociology abstracts the structuring principles which provide the order within the flux' (Smith, 1989: 23).

\footnotetext{
${ }^{1}$ I have elsewhere attempted at a more chronological (if sketchy) approach (Almila and Inglis, 2022).
} 
Using the term 'vignette' instead of 'snapshot' has obvious etymological benefits for a wine researcher-it derives from 'vigne', French for 'vine'. But the termit also balances out what is something of a bias in the word 'snapshot', which indicates something that is both visually oriented and frozen in time. Although 'snapshot' has the benefit of stressing the agency of the researcher in choosing what to take a picture of, to freeze an object in time (in and through writing), I find the metaphor lacking in recognition of the interconnectedness of the various elements of the structure(s) from which each vignette arises in the case of genderedness of wine. The vignettes I have chosen tell stories through times and places, thereby weaving together unexpected elements and conjoining multiple symbolisms. ${ }^{2}$ This method of selection and presentation allows me to make connections between historically, culturally, and geographically diverse wine-gender phenomena that otherwise might not be apparent.

Academic and quasi-academic texts concerned with wine and gender have variously approached the subject by focussing on women working with wine (Almila, 2019; Brenner, 2007; Bryant and Garnham, 2014; Matasar, 2006; Ody-Brasier, 2017), women's and men's wine consumption habits (Atkin et al., 2007; Barber et al., 2006, 2010; Dlačić and Kadić-Maglajlić, 2013; Johnson and Bastian, 2007; Nicolson, 1990; Ritchie, 2009; Thach, 2012), and historical and contemporary wine-gender relations (Almila and Inglis, 2022; Bianquis-Gasser, 1992; GefouMadianou, 1992; Matasar, 2006; Phillips, 2018). I find all these areas fundamentally intertwined, and that is why I do not approach wine and gender primarily through any particular one of them. My examples are mostly drawn from wine consumption and popular culture, with some reference to wine production and wine languages. I am interested in what sorts of gendered boundaries wine builds and breaks, and what kinds of taboos and threats are present in wine-gender relations. In other words, what are the dangers of wine revealed in long-held and contemporary wine beliefs and practices?

In my analysis, I draw upon the classical work of Mary Douglas, especially Purity and Danger (Douglas, 1966). Douglas (1966) argues that cultures and societies must be organised around principles of purity - that which holds communities together-and pollution — that which threatens their integrity. Pollution, or dirt, she famously claims is simply 'matter out of place', not dirty in any essential sense (Douglas, 1966: 41). Pollution is objected to by community members as it threatens existing categories and classifications that order social and cultural understandings.

Culture, in the sense of the public, standardised values of a community, mediates the experience of individuals. It provides in advance some basic categories, a positive pattern in which ideas and values are tidily ordered. And above all, it has authority, since each [person] is induced to assent because of the assent of others. But its public character makes its categories more rigid. A private person may revise his pattern of assumptions or not. It is a private matter. But cultural categories are public matters. They cannot so easily be subject to revision. Yet they cannot neglect the challenge of aberrant forms. Any given system of classification must give rise to anomalies, and any given culture must confront events which seem to defy its assumptions. (Douglas, 1966: 40)

It is, however, out of my reach here to create an analysis of any 'full system of classification' as regards wine and gender (Douglas, 1972: 41). My approach is necessarily limited, but it will hopefully point towards possibilities that this sort of an analysis could offer to a sociologist interested in wine and gender.

A word of clarification may be due-I do not focus much on Douglas's (1987) famous introduction piece to the edited book she published in the 1980s, Constructive Drinking. The reason for this is that, while her account is extremely valuable in pulling research on alcohol away from the exclusive focus on social problems and negative framings that she recognizes especially in medical sociology of the time, I find her suggested approach less fruitful than her older work for the discussion here. However, I quite agree with her claim that '[d]rinking is essentially a social act, performed in a recognized social context' (Douglas, 1987: 4). ${ }^{3}$

\footnotetext{
2 Simmel (2012: 273) mentions wine in one of his three snapshots: 'Through ownership, sooner or later we destroy what we must thoroughly possess in order to enjoy: a roast, wine, and anything we relish with the senses'. This comment follows his reflections as to whether men must possess women or whether they can enjoy women's 'unspeakable beauty' without possession. Apparently wine's beauties cannot be enjoyed without possession, so at least in this sense, women and wine are not equitable for Simmel.

${ }^{3}$ Regarding gender, Douglas's (1987: 7) reflections concern women in a primarily medical light: 'in many civilizations women are habitually excluded from taking strong alcohol. One might look for an ancient wisdom which protects the vulnerable foetus by a general rule applied to all females. If that line is followed what could be said about the sources of such rules? Are they explicitly based on gynaecology or do they result from a happy convergence of medical and social ideas? If women for whatever reason tend to be excluded from alcohol, one can be curious about the health value of the other drinks that would, in a carefully partitioned society, be classed as peculiarly appropriate for women. If the classification has purely social functions, thirsty women or women wanting to celebrate might be driven in default to very unhealthy alternatives. Water is often contaminated; tea and coffee are not perfect health drinks. Furthermore, protection of women from dangerous foods is not universally practiced. Do we expect to find women drinking alcohol freely only when the social norms are broken down?'
} 
It is also perhaps necessary to point out how I came to frame a sociological wine analysis through the work of a famous anthropologist. First, I do not believe in strict disciplinary boundaries in either methodological or analytical terms. Central for a sociological analysis is some sort of sociological imagination, and in this I have always felt Mary Douglas to have excelled. Second, Douglas was fundamentally influenced by the classical sociology of Émile Durkheim, to the extent that she has been considered a 'faithful disciple' of Durkheim (Fardon, 1987). By extending Durkheim's ideas of social classification systems beyond the sacred/profane dichotomy, towards secular forms of purity and impurity (Duschinsky, 2014), Douglas's work opens further vistas for the type of wine analysis I am conducting here.

Therefore, what emerges from my Douglas-inspired approach is a gender-oriented cultural sociological way of looking at wine, analytically working with wine, and understanding wine-gender relations. The boundaries discussed here, it seems to me, are more than symbolic, they are often deeply embodied, too. Yet it is at the symbolic level where the meanings of wine-gender relations are constructed, recognised, and acted upon. How we speak about wine, what wines we drink and do not drink, and who makes our wine, are all elements of gendered cultural structures of wine.

\section{$1^{\text {ST }}$ SIP: WINE, WOMEN AND SONG}

The 1959 comic music hall song Have Some Madeira M'Dear, tells a story of male-female wine-based relations that reflects centuries-old perceptions of supposed female vulnerability to alcohol and wine's apparent threat to sexual purity (Almila and Inglis, 2022; Dietler, 2006; Phillips, 2018).

The female target of a planned seduction by a disreputable older man is introduced as a fundamentally innocent creature:

She was young, she was pure,

She was new, she was nice,

She was fair, she was sweet seventeen.

Whereas the male protagonist is her very opposite:

He was old, he was vile, and no stranger to vice, He was base, he was bad, he was mean.

After luring the lady into his flat, the seducer moves on to intoxicate his victim.

And he said as he hastened to put out the cat

The wine, his cigar and the lamps:

'Have some Madeira, m'dear,

You really have nothing to fear;

I'm not trying to tempt you, that wouldn't be right,

You shouldn't drink spirits at this time of night.'

The threat to her purity is expressed in terms of a fundamental sexual misbalance between the genders, where the male is the chaser and the violator, threatening to irreversibly spoil the previously 'untouched' female.

Unaware of the wiles of the snake in the grass,

Of the fate of the maiden who topes,

She lowered her standards by raising her glass,

Her courage, her eyes, and his hopes.

She sipped it, she drank it,

She drained it, she did,

And he quietly refilled it again

The sneakiness (or snakiness ${ }^{4}$ ) of the male protagonist is apparent in his assurances that the wine he offers to his intended victim is safe, as it is 'only' wine and not an alcoholic spirit. But as destruction looms over the thirsty maiden, she is saved by — what else — the final words of her dying mother:

\footnotetext{
${ }^{4}$ Snake is of course the long-standing symbol of impure temptation in Judeo-Christian tradition, to whose promises the female of the species is supposed to be particularly defenceless.
} 
Then there flashed through her mind what her mother had said

With her antepenultimate breath

'Oh my child, should you look on the wine that is red

Be prepared for a fate worse than death'

The mother's words bring ambiguity to the role of the snake-is it the man, or the wine? Notwithstanding the question as to whether Madeira is 'wine that is red' (it is not a red wine, nor red in colour), the mother's warning causes the heroine to flee.

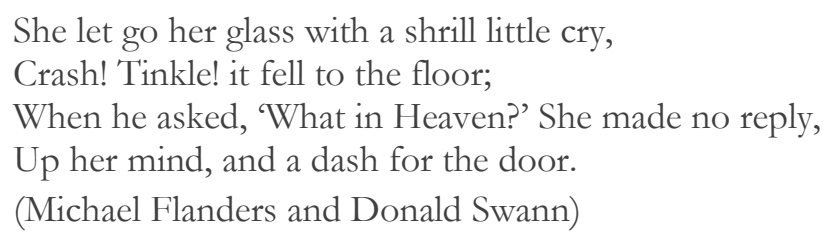

I chose this song as the first vignette for two reasons. First, it exemplifies very old cultural assumptions about, and representations of, women's vulnerability to wine in terms of seduction and sexual licentiousnessassumptions expressed already in ancient Greek plays, as well as in medieval European literature, namely Decameron (Almila, 2019; Almila and Inglis, 2022). Second, it illustrates a moment in history-the late 1950s and early 1960s - when things were beginning to change. The following decades would witness women's increasing entry in public spaces, including spaces for alcohol consumption, where they previously had often risked being considered as prostitutes or as otherwise sexually available (Langhamer, 2003; Ludington, 2013; Phillips, 2018). The range of acceptable drinks for women grew, and spaces explicitly marketed for female wine consumption increasingly emerged in Europe, North America and East Asia (Ho, 2015). ${ }^{5}$

The types of misogynistic attitudes Madeira M'Dear comments upon and uses still survive today. For example, sexism of wine languages and wine labels has been commented upon by female wine professionals and others (Ayscough, 2020; Kavanaugh, 2016), and although 'wine glass ceilings' have been broken by an increasing number of women, their experiences of career disadvantages, discrimination, and outright harassment and abuse have by no means disappeared (Robinson, 2017). Yet, women's opportunities for consuming, producing, and working with wine have significantly changed from the times when wine and women were both considered goods to be consumed (Dolan, 2018).

\section{$2^{\text {ND }}$ SIP: WINESMANSHIP}

One-Upmanship is a parodical self-help book by English satirist Stephen Potter (1952: 136), featuring a section on 'winesmanship': 'How to talk about wine without knowing a Hock from a Horse's Neck'. The book is a sequel to The Theory and Practice of Gamesmanship (or the Art of Winning Games without Actually Cheating) (1947). In winesmanship, the aspirational male, seeking to win advantage over other men (and impress women in the process) is given advise for ordering, choosing, and talking about wine. In a restaurant,

look at the wine list before the waiter comes and say, 'Amazing. Nothing here you can be sure of. Yet the food is quite good. But I've got an idea.'

Then, when the waiter comes, say to him, 'Look. You've got a Château Neon '45 somewhere secreted about the place, I know. Can you let us have a bottle?'

(You know he's got it because you have in fact read it off the wine list, cheapest but one.)

When the waiter leaves, you can say, 'They keep a small cache for favoured customers.' (Potter, 1952: 137)

Likewise, when giving a home dinner for guests, the important weapon is self-assurance:

remember that your mainstay is hypnotic suggestion. Suggest that some rubbishy sherry, nine bob ${ }^{6}$, is your special pride, and has a tremendously individual taste. Insist on getting it yourself 'from the cellar.'

Take about four minutes uncorking it. Say, 'I think decanting destroys it,' if you have forgotten, or are

\footnotetext{
${ }^{5}$ Spaces for specifically female alcohol consumption appeared in the US in the late $19^{\text {th }}$ century (McClellan, 2017; Remus, 2014), but a wider access to such spaces followed only later.

${ }^{6}$ 'Nine bob' means nine shillings. There were 20 shillings in a pound, so nine shillings would be less than half a pound.
} 
too bored, to decant it. Keep staring at the bottle before you pour it. When you have drawn the cork, look particularly hard at the cork, and, of course, smell it. (...)

[You should] talk in broken sentences and say, 'It has... don't you think?' Or, 'It's a little bit cornery,' or something equally random like 'Too many tramlines.' I use this last phrase because it passes the test of the boldly meaningless. (Potter, 1952: 137-139, emphasis in original)

Poking fun at pretentious language used by some wine connoisseurs, Potter also laughs at the aspiring man seeking to establish his status through a variety of means, including wine talk. He also indicates that he assumes the audience (whether male or female) of the aspirational man to be as ignorant as the aspirational man is himself. The book does not explicitly comment on the expected audience, but in the 1960 film adaptation of the novels, School for Scoundrels, these lessons are put into action in order to impress a woman and shame a romantic competitor. The protagonist Henry Palfrey (Ian Carmichael) successfully asks out April Smith (Janette Scott), but is then made a fool of in a restaurant by the (overly) confident Raymond Delauney (Terry-Thomas) who shamelessly seeks to woo April in front of Henry. Neither Henry nor April is able to see through Raymond's empty wine talk.

The status brought on by talking the wine-talk is very real indeed. 'Connoisseurship', writes Mary Douglas (2003: 9), 'has its own power for social domination. Who could afford to let the hotel waiter get the upperhand and yet, how much expertise is needed to stop the waiter from forcing a humiliating dependence upon himself?' A man must impress not only his lady, but (perhaps most importantly) other men, too. Douglas (1987: 9) enters into a relevant vignette-type reflection right in middle of her introduction to Constructive Drinking, where she comments upon the remarkable wine-tasting abilities of the fictional gentleman detective Lord Peter Wimsey (created in the early 1920s by Dorothy L. Sayers), whose many and varied skills involve the capability of flawlessly blind-naming port vintages, indicating both his high social status and his extreme competence in exclusive class performance. Wine language and talk are not only gendered in multiple ways (Inglis, 2019), they are also deeply classed. ${ }^{7}$ Symbolic boundaries can be drawn through symbolic dominance expressed and exercised through expertise in wine language.

\section{$3^{\text {RD }}$ SIP: LADIES' HALVES}

'What on earth comes over wine waiters when they take the orders of a woman entertaining another woman in a restaurant?', asked the British food writer Elizabeth David in the early 1960s. She was referring to the difficulty of getting served a whole bottle on such occasions.

There are occasions when a half is what one wants, a half and nothing else, in which case I really don't believe one has to be a master-woman to be capable of specifying one's wishes in the matter. I suppose the assumption on the part of wine waiters that women are too frail to consume or too stingy to pay for a whole bottle must be based on some sort of experience, but instead of having to go back to change the order $(. .$.$) he could inquire in the first place, in a discreet way. Or even in an indiscreet way, like the$ steward on the Edinburgh-London express a few years ago who yelled at me across the rattling crockery and two other bemused passengers, 'A bottle madam? A whole bottle? Do you know how large a whole bottle is?' (David, 2009: 46)

The idea that women are naturally less able to hold their spirit (or wine) goes back thousands of years (Almila and Inglis, 2022; Dietler, 2006; Matasar, 2006). But rarely today does one meet such treatment as David describes as a woman in restaurants: some things clearly have improved. Indeed, nowadays sommeliers and other restaurant service staff are likely to even enquire who is going to taste the wine, rather than assuming the male member of the party should do so (see Almila, 2019: 196).

Yet female and male wine consumption are perceived differently. In parts of the world, such as the US and UK, women are major wine buyers (Barber et al, 2006; Phillips, 2018; Ritchie, 2009; Thach, 2012), and female wine consumption is increasingly culturally normalised (Kennedy, 2017), but concerns about women drinking alcohol remain. In such discourses, the gendered body is often medicalised, and different acceptable alcohol consumption levels for men and women are typically imposed by healthcare bodies and governments. ${ }^{8}$ It is not exceptional to see wine marketers claim that women want (or at least prefer) low-alcoholic wines (Almila, 2019). Women and

\footnotetext{
${ }^{7}$ Wine language has also been accused of being colonialist in the sense that standardised tasting vocabulary draws upon geographically specific culinary traditions, and its expressions thus are often incomprehensible to wine enthusiasts from other world regions (Mobley, 2020).

${ }^{8}$ This is not the case everywhere- the UK and New Zealand, for example, recommend same limits for everyone, whereas the US and most Nordic countries make a distinction between men and women.
} 
alcohol is a deeply conflicted realm: women's alcohol consumption may be both demonised (particularly in the case of pregnant women and the Fetal Alcohol Syndrome (Armstrong and Abel, 2000)) and considered automatically less problematic than men's (McDonald, 1994), as happens when the category of alcoholism is primarily reserved for men (McClellan, 2017).

The female body political operates 'between the micropolitics of enhancing the health of individual bodies and the macropolitics of maintaining and re-creating social, political, and often global regimes of power' (Saukko and Reed, 2010: 6), perhaps particularly strongly so when human reproduction is considered. Concerns to do with women, wine and adultery (Phillips, 2018), female alcohol consumption during pregnancy (Armstrong and Abel, 2000), and wine-drinking and motherhood (Killingsworth, 2006) are all concerns to do with human reproduction and the reproducing female body. The most important factor to be monitored in such concerns is typically the amount of alcohol consumed by the woman, even when the woman consumes a more socially acceptable type of drink, such as wine.

Despite wine's normalisation as an admissible drink for (middle-class) women (Kennedy, 2017), and the increasing normalisation of women's wine consumption especially in Western and Northern Europe, North America, and increasingly in East Asia (Zhou, 2018), women's alcohol consumption may still be judged against different standards from that of men. ${ }^{9}$ Working class women, in particular, tend to be more harshly judged for public drunkenness (Skeggs, 2005). Today, also online environments function in the construction of one's public image as regards alcohol consumption. Again, working class women face harsher criteria-they may be considered to be 'faking' if posing with wine (or champagne) glasses, when similar display from middle-class women is taken to indicate relaxation and carefree attitude (Lennox et al, 2018: 18). The class (glass) line for women in these cases operates in terms of standards of behaviour, and assumed motivations behind the woman's drinking habits and the display thereof. It seems that while for a man, it is important to know about wine and to demonstrate such knowledge, for a woman, it is important to behave when drinking wine.

\section{$4^{\mathrm{TH}}$ SIP: THE RED PERIL}

In book VII of his Natural History, published in $77 \mathrm{CE}$, Pliny the Elder warned of severe dangers to do with 'the monthly flux of women. Contact with it turns new wine sour, crops touched by it become barren, grafts die, seeds in gardens are dried up, the fruit of trees fall off (1942: 540). Almost 2000 years later, a Canadian woman of Italian immigrant background reminisced about her childhood in seasonal wine pressing:

For many Italian immigrants and their families in Toronto, pressing wine is an annual autumnal event in garages and basements around the city. ${ }^{10}$ One wine-making season, when I was twelve years old and had just begun to menstruate, my grandmother took me aside and discreetly asked if I was 'on my period'. Sensing that something was amiss, I hesitated for a moment before saying yes. She put her arm around my shoulders and steered me away from the basement stairs, gently telling me that she was sorry, but I would not be able to help with the wine that year-it would be bad luck. I was banished from the basement because my blood was a curse. I tried not to care about being excluded, but to be told that my presence might sour the wine due to a natural process beyond my control was a decidedly odd and unwelcome feeling. (Pietropaolo, 2016: n. p.)

Pliny's claim concerned specifically young wine, as well as other young, growing, or potentially growing things. Whether old wine might be spoiled by contact with menstrual blood remains unclear, as does whether mere contact with a menstruating woman would be perilous. Anomalous, out-of-place substances are not automatically polluting, they may be powerful in good and bad (Douglas, 1972). But anthropologists have argued that ' $[\mathrm{b}]$ ecause menstrual blood and menstruous women are perceived as dangerous, taboos have been devised to contain their energies and keep these from spreading beyond a limited place in the order of things' (Buckley and Gottlieb, 1988: 25).

Wine, too, is magical, powerful, and potentially dangerous (Inglis, 2022). In some folkloric traditions, it is a bringer of good health, 'good blood'. Especially '[r]ed wine, life's blood, was closely associated with manhood and virility' (Del Giudice, 2000). Red wine is also central to Christianity, both symbolising and turning into blood through sacrament. In this sense, wine is deeply spiritual and religious.

\footnotetext{
${ }^{9}$ However, in Denmark, wine is considered as an altogether 'safer' form of alcohol than spirits, but it is important for both genders to demonstrate that they are in control of their drinking (Grønkjær et al., 2011).

${ }^{10}$ If the reader is surprised with the idea of wine production in Toronto, what is referred to here is home making of wine in Italian-background immigrant families. Grapes were often imported from more southern locations, such as from the southern US, or grown in backyard gardens, and the winemaking held strong family and homeland connotations. Results were varied and rather unreliable (Del Giudice, 2000).
} 
From the examples above, it seems that wine may have been especially vulnerable to other types of magic when in preparation or still young - a veritable battle of magics. ${ }^{11}$ Wine's vulnerability only in its infancy and youth is supported by another, negative proof. I have not come across any records that would indicate that menstruating women would be automatically banned from serving wine. ${ }^{12}$ Rather, bans on female presence (whether menstruating or not) have concerned spaces of making wine, such as wine cellars (Matasar, 2006).

Yet superstitions weaken and disappear over generations. Winemaker Sylvie Courselle's grandmother was not allowed in the cellar, but the granddaughter now runs the family estate with her sister (McCoy, 2020). Similarly, Pietropaolo's childhood experiences of being banned from winemaking changed with time:

After that day by the basement stairs, my grandmother never again asked about my period. Her expectation was that I was responsible for policing myself. When I was fifteen, I had terrible menstrual cramps and was late to help harvest the backyard grapes. I was worried that I might curse the grapes, and asked my mother what to do. She brushed it off at first, dismissing the possibility—but then she paused, suggesting that I not mention it to anyone, just in case. (Pietropaolo, 2016: n.p.)

With red wine's symbolic connection to blood, it is perhaps not altogether surprising that another link to menstruation has more recently emerged. Red wine is apparently capable of helping women with menstrual cramps. Red wine has been medicalised in many ways, declared healthy for the heart, or helpful with diabetes and dementia (Skerrett, 2012). From magical, (red) wine has turned into medical, and this medicalisation has reached out to periods, too.

The language of non-medical online reports offering red wine as a solution to menstrual pain is often a fascinating mixture of (would-be) science and other types of expressions, as is the case with a report by Wine Tasting Bled (n.d.: n.p.), promoting Slovenian wines. Menstrual cramps are described as 'excruciating' and 'agonizing', and different kinds of statements are mixed. There are claims that resveratrol, found in red wines, can thin blood, therefore reducing blood clots, and that alcohol can prevent the formation of scar-tissue. ${ }^{13}$ But there are also dubious deeply sensory claims, such as that red wine is better against menstrual cramps than white wine, as it 'warms the body'.

Wine has of course been used for medical purposes well before this (Martin, 2001). What is interesting is that wine's magic seems to have made a full round-not threatened by menstrual blood anymore, but capable of exposing its own power upon the bleeding woman and her womb.

\section{$5^{\mathrm{TH}}$ SIP: WINE FOR WOMEN}

When writing this paper, I googled 'wine for women'. The first hit, to my astonishment, was a list of ' 6 best girly wines', as follows (Remedy Liquor, 2018):

1. Château d'Esclans Rock Angel, France [rosé wine]

2. Happy Bitch Rosé

3. Bottega Sparkling Moscato

4. Chocolate Shop, The Chocolate Lover's Wine

5. Cabernet Sauvignon

6. Pinot Noir

This list illustrates some strikingly stereotypic assumptions regarding women's wine (and other) tastes. First, women like pink, sparkling and sweet (Moscato is a sweet style of sparkling). Second, women love chocolate (sweet!). And third, it does not matter what sorts of characteristics specific red wines have, to pop out a name of a grape is quite enough. Also, one must not forget that the word 'bitch' is always a good marketing trick (see also Almila, 2019: 197 on Skinny Prosecco).

To be fair, just as Elizabeth David (cited above) thought, there probably is a lot of experience behind such lists. Marketing researchers have demonstrated that women are typically less interested in, or confident with, discussing wine's technical characteristics than are men (Thach, 2012). Research has also confirmed the tendency of women and men to prefer different wines, to conduct their wine shopping differently, and to consider their levels of wine

\footnotetext{
${ }^{11}$ Interestingly, Picard et al. (2018) argue that wine continues to be magical today, in how it is understood to transform and contain the power of specific terroir.

${ }_{12}$ Obviously, menstruating women in different cultures may be completely banned from contact with others (Buckley and Gottlieb, 1988), but this does not seem to be directly the case with wine.

${ }^{13}$ As a sociologist, I am obviously not qualified to evaluate how medically reliable or not these claims are. However, Skerrett (2012) is critical of laypersons' and journalists' use of medical research results in an overgeneralising manner, drawing too farfetching claims from tentative or limited scientific findings. Such, according to him, is often the case with resveratrol mentioned here.
} 
expertise differently (Barber et al., 2006, 2010; Johnson and Bastian, 2007; Ritchie, 2009; Velikova et al., 2015). Women tend to be less self-confident and estimate their wine knowledge as lower than men, even when that would technically not be true (Zhou, 2018). Shopping and consumer practices and experiences, and perceptions of one's own wine expertise level deeply influence individuals' wine choices and preferences, as well as the wine language they are likely to use.

Producers have taken the que. Thus, sweeter rosés are explicitly marketed to younger women (Gabay, 2018). Women are offered wines with lower alcohol and calorie levels (Almila, 2019). All this is supposed to reflect 'what women want', but at the same time it brings the category of female wine consumer into existence. If gender is, as Judith Butler (1988: 519) insists, 'a stylized repetition of acts (...) instituted through the stylization of the body (...) the mundane way in which bodily gestures, movements, and enactments of various kinds constitute the illusion of an abiding gendered self, then the female wine consumer is what she (is supposed to) consume/s when she lifts her wine glass to her lips.

Yet, taste for food and beverages, when considered in light of a larger body of research, is not radically divided by gender. 'Based on an exhaustive review of the literature that has been published over the last century, the conclusion was reached that while there are indeed a number of marked individual differences in multisensory taste/flavour perception, few if any fall neatly along sex/gender lines' (Spence, 2019: 3). It is also the case that marketing wine (or anything else) too explicitly for women may well backfire, provoking criticism or ridicule rather than commercial success. Often, implicit marketing for women works better than publicly announcing that something is 'for women', especially if the product is generally considered very ungendered in character. But in such subtle marketing lies also the effectiveness of gender performativities-the less openly something is declared to be deeply gendered, the more powerful and world-shaping its genderedness may be (Butler, 1988). The differences in female/male wine consumption habits found by researchers may well be an illustration of this.

\section{$6^{\text {TH }}$ SLURP: THE BATTLE OVER (B)ROSÉ}

\section{In 2012, the food writer Jason Wilson commented on an encounter with a male friend regarding rosé wine:}

'What are you, a girl? Is this Girls' Night Out?' That's what a friend, an investment banker, said on a recent evening as the waiter delivered my glass of rosé wine to the table. I considered my manly friend, from his pink tailored shirt to the insipid Coors Light he was drinking. 'At this stage of my life,' I said, 'I'm comfortable enough in my manhood to drink pink wine.' Yeah, that's right. I'm man enough to profess my fondness for rosé wines, especially on a steamy summer evening, before dinner as the sun begins to set. (Gabay, 2018: 283)

Wilson (2015: n.p.) has commented on male angst over rosé wine in other occasions, too.

Like every spurious lifestyle trend, this tendency [of men to drink rosé wine] came with a portmanteau. The bros imbibing pink wine were part of the 'brosé phenomenon', (...) [and] aspirational millennials with creative jobs were wheeled out to assure us that while they once would have felt self-conscious about drinking rosé, in the summer of 2015 they may finally 'drink pink' without blushing.

Often considered a wine for the young and the beginners, rosé wine has nevertheless become increasingly fashionable in the 2000s. Media accounts of both fashionability and sophistication have supported industry efforts to increase rosé's market share (Gabay, 2018). Celebrity involvement-notably so in the case of male celebrities radiating hegemonic masculinity, such as the former Top Gear host Jeremy Clarkson—and luxury (fashion) brands, including LVMH (Moët Hennessy Louis Vuitton), Chanel, and Dolce \& Gabbana, have pushed rosé wine towards the luxury market (Shaw, 2020). Wine critics have played their part, too, arguing that rosé wine traditions are an integral part of the proud and laudable French wine traditions, and thus merit a higher status for rosé than had previously been the case (Fitzmaurice, 2017). A wide-spread narrative of pale Provencal rosé's superiority over others has globally pushed producers towards producing paler hues of their beverage, whether this has traditionally been the case in the area or not (Gabay, 2018).

The colour pink needs a further clarification here. What some consider 'anxieties about pink's feminizing abilities' have a long history. In $16^{\text {th }}$ and $19^{\text {th }}$ century art, pink represented 'artificiality, superficiality, seduction, and femininity'. $19^{\text {th }}$ and $20^{\text {th }}$ century fashion marketing reflected similar associations, playing with 'the deeply seductive power attributed to color' (Grisard, 2017: 78, 79). The US fashion industry was a great driver of pink in the 1950s. Pink fashion spread from garments to domestic spaces, and even men were urged to wear pink in the mid-1950s (Blaszczyk, 2012). But most importantly, 'in the 1950s pink became attached to a new feminine beauty ideal'. The beauty ideal was more conservative and less active than before the WWII: 'Whoever fell prey to the allure of color was deemed weak-willed and emotional, personality traits commonly attributed to women' (Grisard, 2017: 79). In 
the years to come, pink came to demarcate not only gender boundaries, but also boundaries of sexual orientations, thus making the colour even less appealing to the heterosexual and heteronormative man (Koller, 2008).

This is part of the background in which rosé's danger to heteronormative masculinity is grounded, although the taboo of pink fashion for men had arguably already been broken when the manly wine drinkers were only familiarising themselves with the pink drink-Jason Wilson's friend made his snarky comments about rosé while wearing a pink shirt. ${ }^{14}$

Rosé wine posed two threats to the masculine heterosexual male drinker: it was not considered a serious connoisseur beverage; and it had been considered a girls' or women's drink, due to both its colour and associations thereof, and its (assumed) taste and characteristics (supposedly sweeter and less alcoholic). ${ }^{15}$ It is indeed the case that rosé's image is often considered 'unsophisticated, seasonal and feminine', although more recent research indicates that its perceived 'femininity' may today not be as strongly felt by consumers as is often assumed (Velikova et al., 2015: 283). In fact, a collective effort has been made to bring rosé wine into the realm of greatness: 'Through explicit and implicit comparisons, rosé was recast [by critics] as a serious wine and stripped of its feminine, lowstatus associations. Critics then invested the category with new meanings, using elite consumers and lifestyles as the referents for its worth' (Fitzmaurice, 2017: 1).

On the other hand, it has been argued that the French millennial generation's love of rosé exists precisely because the wine is considered not sophisticated, and fundamentally feminine (both in character and in colour). This can be considered as a rejection of the older French generations' taste for 'masculine' and elitist red wines (Lorey, 2021). Thus, while rosé is not necessarily considered a 'serious' wine in France, it can be (and is) consumed by men and women alike (Velikova et al, 2015).

Regarding performances of masculinity, it is particularly interesting that Jason Wilson says he is 'man enough' to drink rosé-thus turning his drinking firmly away from being 'a girl', or effeminate. He could have said he drank rosé to embrace his femininity, but instead chose to frame it as an activity associated with secure self-esteem and thus hegemonic masculinity (Donaldson, 1993). So, too, did the sommelier Thomas Pastuszak in 2015: 'I like to say that real men drink pink' (Wyma, 2015: n.p.). By such acts, again, are genders and gender boundaries brought into existence and affirmed. Normative masculinities are not challenged through these sorts of statements; just as rosé wine was not accepted by critics 'in its own terms' but needed to brought into the realm of 'greatness'. Instead, the image of rosé wine (and the image of the colour pink in certain contexts) is changed to fit into the established boundaries of masculinity.

\section{$7^{\text {TH }}$ MOUTHFUL: THE SCENT OF A WOMAN}

Sommelier Victoria James opens her autobiography Wine Girl (2020) with a vignette that gives name to the whole book. She was only 21, and at the beginning of her career, when an obnoxious male customer decided to humiliate her, for the (presumed) enjoyment of his friends. He claimed that a perfectly good bottle of rare, prestigious, and expensive Burgundy Chardonnay that James was serving him during a Monday lunch was corked:

'I think she has too much perfume in her nose, this girl...' His glare turned upward and at me. 'The bottle is corked, take it back. Bring us another.' (...) 'Listen, wine girl, I have bottles in my cellar older than you. I know when a wine is corked.' (James, 2020: 5)

\footnotetext{
${ }^{14}$ Talking of other manly men, the secret agent James Bond has so far drunk rosé wine once on the screen: in Thunderbolt (1965), Sean Connery holds a glass of rosé wine when visiting a swimming pool (Ross, 2021). It must be noted that he also wears a pink shirt on the occasion, so perhaps the wine was simply chosen to match his attire - the wine's hue is certainly darker than any 'respectable' Côte de Provence would be. Mr Bond has recently inspired rosé wine marketing, too. Rosé's marketing-into-fashion has often drawn upon associations with summer and glamour (Gabay, 2018)—such glamour marketing having been used successfully for a long time by Champagne houses and brands (Almila, 2021; Harding, 2021; Rokka, 2017). The marketing imagery of the UK-based but Provence-producing Brosé wine brand does not radically differ from these traditions. One of the brand's 'inspiration' images in October 2021, just when his last Bond film No Time to Die had premiered, was the actor Daniel Craig in a pink velvet jacket. The Brosé brand goes for well-established markers of masculinity—sports cars, speed boats, and bikini-glad women at swimming pools (potentially to be seduced, of course). It is all summer and relaxation, presented as something that men 'want to be associated with' (Brosé Wine, n.d.).

15 Colour affects how we experience and taste wines (as do other elements, such as sound, according to the idea of 'multisensory flavour perception') (Spence, 2015, see also Ross, 2014). Packaging colour, too, 'affects (...) expected and perceived taste and flavour (...) of beverage products' (Spence and Velasco, 2018: 226). The colour pink has been associated with sweetness across many locations (Spence and Levitan, 2021). Their dryness may well be part of the 'credibility' and desirability of the pale coloured rosés, while global middle-class tastes have increasingly turned towards drier wines altogether, irrespective of gender (Howland, 2019).
} 
The general manager agreed with James that the wine was in perfect order and told her to serve it. The expensive wine would otherwise have been wasted. Between a rock and a hard place, James decided to serve the same bottle to the customer, pretending that it was a new bottle. This time the man was perfectly happy with the wine, but had more to say about James's persona:

'A woman, a young woman... probably too much perfume in her nose... could there be anything worse in a sommelier?’ (James, 2020: 7)

Wine Girl is not solely a story of misogyny and belittling, but it does lay out many struggles a woman, and a young woman especially, may encounter when embarking on a wine career. It also reflects interestingly on decadeslong commentaries on women's presumed perfume-usage.

Nothing changed as wine drinking spread to the New World. Private gentlemen's clubs and all-male dinner parties were the direct descendants of the earlier symposia and convivia. The collegiality, intellectual sophistication, and learning long associated with wine consumption remained identified with male-only environments. Additional, more 'modern' biases were added to the longstanding concerns regarding female wine consumption. The ability to appreciate wine's nuances became associated with masculinity. Some assumed that women would spoil tastings by wearing perfume that detracted from the wine's bouquet. (Matasar, 2006: 7)

A professional woman (other than a prostitute-see Phillips, 2018) may thus spoil the exclusively male space that some men feel entitled to. She is matter out of place (Douglas, 2001 [1966]), a threat expressed in a fear of an imagined scent.

The myth of perfumed women spoiling gentlemanly fun seems persistent indeed. Decades earlier, Britain's first serious female wine writer, Pamela Vandyke Price (1923-2014), had experienced something very similar-although at the time she was able to challenge the man accusing her of wearing perfume, as she was not working in the service sector:

Once, (...) I remember, I was summoned from the office to the tasting-room where a loudly-spoken man greeted me with 'Ah—the ladies have come! Now we shall not be able to taste anything!' (...) I then asked this person why? 'Oh—you know—all your scents and smells.' 'I can smell the preparation you use on your hair,' I said[,] 'the cleaning fluid that has been used for your suit, your boot polish—and you have a pipe in your pocket!'

Of course I took great care never to introduce a scent into the tasting-room. (...) Nothing scented was used on a tasting day and I brushed through my hair with water as a precaution. (Price, 1990: 120)

Operating in very much a man's world, Vandyke Price's wine experiences were nevertheless more privileged than James's. Vandyke Price was a protegee of powerful men, and from a fairly privileged background herself. She became a professional wine writer somewhat by a chance, and partly due to her husband's early death. ${ }^{16}$ Yet the prejudices, forms of misogyny, and insults that professional wine women encounter seem to have changed little in character. Women's presumed perfume-wearing is seen as a sign of weakness, whereas male perfumes and cosmetics are considered 'neutral'. ${ }^{17}$ And perfume or not, some men see it fit to altogether doubt a woman's ability to taste wine, and, indeed, recognise a corked wine (Almila, 2019: 205-206; MacLean, 2007: 243).

It is worth mentioning here that some female wine professionals (and I have myself interviewed some-see Almila, 2019) argue that men and women smell and experience wine differently because of hormones. Some argue that women are naturally better tasters, due to an averagely higher number of taste receptors on their tongues (Robinson, 2017). While hormones obviously influence the workings of the body, this can also be understood as another instance of magic turned into medicalised (or biologicised) terminology. Wine's magical capacities intertwine with the magical capacities of the gendered body, thus carrying beliefs and expectations into the future of wine, too.

\footnotetext{
${ }^{16}$ Vandyke Price (1990) recognised herself as a sort of a 'wine widow', referring to a long line of women (most famously Barbe-Nicole Ponsardin Clicquot) who became powerful in wine through their widowhood (see Matasar, 2006).

${ }^{17}$ Female perfume is, indeed, often considered dangerous, indicating threatening, active female sexuality (Dugan, 2011; Stewart, 2020).
} 


\section{THE (SHORT BUT LINGERING) FINISH}

Wine reflects wider gender relations. It reveals gender norms, and constructs and establishes gender boundaries. But wine affords resistance too, which has often been considered threatening to social patriarchal order (Almila and Inglis, 2022). Therefore, wine has historically been restricted and regulated, or even banned from female drinkers. As wine has become a more socially acceptable drink for women, capitalist and consumerist advances have consequently followed. Capitalist wine markets have normalised female wine consumption, in order to enhance profit to be accrued from this vast market sector. But as part of the process, the female wine market has been essentialised as less sophisticated, less knowledgeable, and less confident than the male market. Arguably, few gender boundaries have been radically changed when doing this-it is easier to rebrand a type of wine using established hegemonic gender norms, than to question the norms underpinning gender boundaries.

But wine has other characteristics as well, which might be called magical. According to Alexander and Smith (2020: 263), '[c]ultural sociology emerges from the paradox that societies today are not nearly as rational as they would like to think they are'. So, too, with wine: it remains magical at a deep, often unacknowledged level. Not all wine is magical, though. '[W]ine without recognized and authenticated place of provenance and vintage year would be stripped of most of its magic. It becomes cheap booze ('plonk') or cooking wine' (Picard et al, 2018: 527). Wine is magical because it is seen to carry the characteristics and power of a specific place (and often time), which is the case with the more prestigious and more 'special' wines, favoured by connoisseurs and enthusiasts. Another manner in which wine is magical today is in terms of health: especially red wine is considered healthy in numerous ways. Red wine is also the wine usually considered the most 'masculine' of wines. While the belief that women are capable of polluting wine has more or less died out, it seems that wine's magic today still reflects patriarchal structures in that the most magical of wines are associated with masculinity either through connoisseurship, or through their red character.

Gender is not the only boundary that wine builds and establishes. I have already mentioned that wine drinking, wine talk, and behavioural standards when consuming alcohol are all classed as well as gendered. Further reflections might be made regarding the intersectionality of wine boundaries, most importantly as regards race, ethnicity, and racialisation (Inglis and Ho, 2022)..$^{18}$ Non-binary genders and gender neutral wine languages would certainly merit more attention, too (Pariseau, 2021). Also in these kinds of reflections I believe that a Douglasian approach would be helpful, as it has the potential to reveal very deep levels of cultural structures, thereby bringing to light the most fundamental of socio-cultural borders and boundaries.

\section{REFERENCES}

Alexander, J. C. and Smith, P. (2020). COVID-19 and symbolic action: Global pandemic as code, narrative, and cultural performance. American Journal of Cultural Sociology, 8, 263-269. https://doi.org/10.1057/s41290-02000123-w

Almila, A. (2019). Wine, women and globalization: The case of female sommeliers, in D. Inglis and A. Almila (eds), The Globalization of Wine (pp. 191-212). London: Bloomsbury. https://doi.org/10.5040/ 9781474265027.ch-011

Almila, A. (2021). Fabricating effervescence: Creating, maintaining, and defending Champagne's bubble(s). M/C Journal, 24(1). https:// doi.org/10.5204/mcj.2741

Almila, A. and Inglis, D. (2022). Threats of pleasure and chaos: Wine and gendered social order, in S. Charters, M. Demossier, J. Dutton, G. Harding, J. Smith Maguire, D. Marks and T. Unwin (eds), The Routledge Handbook of Wine and Culture (pp. 311-319). London: Routledge.

Armstrong, E. M. and Abel, E. L. (2000). Fetal alcohol syndrome: The origins of a moral panic. Alcohol \& Alcoholism, 35(3), 276-282. https://doi.org/10.1093/alcalc/35.3.276

Atkin, T., Nowak, L. and Garcia, R. (2007). Women wine consumers: Information search and retailing implications. International Journal of Wine Business Research, 19(4), 327-339. https://doi.org/10.1108/ 17511060710837454

Ayscough, A. (2020). Natural wine labels on the borderline. Available at: https://www.wine-businessinternational.com/wine/general/natural-wine-labels-borderline (Accessed 6 December 2021).

Barber, N., Almanza, B. A. and Donovan, J. R. (2006). Motivational factors of gender, income and age on selecting a bottle of wine. International Journal of Wine Marketing, 18(3), 218-232. https://doi.org/10.1108/ 09547540610704774

\footnotetext{
18 At the risk of leaving a very nasty aftertaste indeed, I must mention that the story of James (2020) discussed above ended with the unpalatable customer deciding that there was one thing potentially worse in a sommelier than being young and female, namely being of ethnic minority. He obviously did not use as nice language in his expressions as I am using here.
}

C 2021 by Author/s 
Barber, N., Taylor, D. C. and Strick, S. (2010). Selective marketing to environmentally concerned wine consumers: A case for location, gender and age. Journal of Consumer Marketing, 27(1), 64-75. https://doi.org/10.1108/ 07363761011012967

Bianquis-Gasser, I. (1992). Wine and men in Alsace, France, in D. Gefou-Madianou (ed), Alcohol, Gender and Culture (pp. 101-107). London: Routledge.

Blaszczyk, R. L. (2012). The Color Revolution. Cambridge, MA: MIT Press. https://doi.org/10.7551/mitpress/ 8762.001.0001

Brenner, D. (2007). Women of the Vine: Inside the World of Women Who Make, Taste, and Enjoy Wine. Hoboken, NJ: Wiley.

Brosé Wine (n.d.) https:/ / brose.world/

Bryant, L. and Garnham, B. (2014). The embodiment of women in wine: Gender inequality and gendered inscriptions of the working body in a corporate wine organization. Gender, Work and Organization, 21(5), 411426. https://doi.org/10.1111/gwao.12045

Buckley, T. and Alma, G. (1988). A critical appraisal of theories of menstrual symbolism, in T. Buckley and A. Gottlieb (eds), Blood Magic: The Anthropology of Menstruation (pp. 3-50). Berkeley: University of California Press. https:// doi.org/10.1525/9780520340565-003

Butler, J. (1988). Performative acts and gender constitution: an essay in phenomenology and feminist theory. Theatre Journal, 40(4), 519-531. https:// doi.org/10.2307/3207893

David, E. (2009). An Omelette and a Glass of Wine. London: Grub Street.

Del Giudice, L. (2000). Wine makes good blood: Wine culture among Toronto Italians. Ethnologies, 22(1).

Dietler, M. (2006). Alcohol: Anthropological/archaeological perspectives. Annual Review of Anthropology, 35, 229249. https://doi.org/10.1146/annurev.anthro.35.081705.123120

Dlačić, J. and Kadić-Maglajlić, S. (2013). The role of gender and situational factors in wine consumption of generation Y. South East European Journal of Economics and Business, 8(1), 53-61. https://doi.org/10.2478/jeb2013-0008

Dolan, F. E. (2018). Time, gender and the mystery of English wine, in M. E. Wiesner-Hanks (ed), Gendered Temporalities in the Early Modern World (pp. 19-46). Amsterdam: Amsterdam University Press. https://doi.org/ $10.2307 /$ j.ctv5qdfst.4

Donaldson, M. (1993). What is hegemonic masculinity? Theory and Society, 22(5), 643-657. https://doi.org/10.1007/ BF00993540

Douglas, M. (1966). Purity and Danger: An Analysis of the Concepts of Pollution and Taboo. London: Routledge.

Douglas, M. (1972). Self-evidence. Proceedings of the Royal Anthropological Institute of Great Britain and Ireland, 1972, 2743. https:// doi.org/10.2307/3031731

Douglas, M. (2003). A distinctive anthropological perspective, in M. Douglas (ed), Constructive Drinking (pp. 3-15). London: Routledge.

Dugan, H. (2011). The Ephemeral History of Perfume: Scent and Sense in Early Modern England. Baltimore: Johns Hopkins University Press.

Duschinsky, R. (2014). Recognizing secular defilement: Douglas, Durkheim and housework. History and Anthropology, 25(5), 553-570. https:// doi.org/10.1080/02757206.2014.928618

Fardon, R. (1987). The faithful disciple: On Mary Douglas and Durkheim. Anthropology Today, 3(5), 4-6. https://doi.org/10.2307/3032886

Fitzmaurice, C. (2017). How rosé became high class: Categorical divestment and evaluation. Poetics, 61, 1-13. https://doi.org/10.1016/j.poetic.2016.10.006

Gabay, E. (2018). Rosé: Understanding the Pink Wine Revolution. Oxford: Infinite Ideas.

Gefou-Madianou, D. (1992). Exclusion and unity, retsina and sweet wine: Commensality and gender in a Greek agrotown, in D. Gefou-Madianou (ed), Alcohol, Gender and Culture (pp. 108-136). London: Routledge.

Grisard, D. (2017). 'Real men wear pink'? A gender history of color, in R. L. Blaszczyk and U. Spiekermann (eds), Bright Modernity: Color, Commerce, and Consumer Culture (pp. 77-96). Basingstoke: Palgrave Macmillan. https://doi.org/10.1007/978-3-319-50745-3_4

Grønkjær, M., Curtis, T., De Crespigny, C. and Delmar, C. (2011). Acceptance and expectance: Cultural norms for alcohol use in Denmark. International Journal of Qualitative Studies on Health and Well-being, 6(4), 8461. https://doi.org/10.3402/qhw.v6i4.8461

Harding, G. (2021). The making of modern champagne: How and why the taste for and the taste of champagne changed in nineteenth century Britain. Consumption Markets \& Culture, 42(1), 6-29. https://doi.org/10.1080/ 10253866.2020 .1713765

Ho, S.-L. (2015). 'License to drink': White-collar female workers and Japan's urban night space. Ethnography, 16(1), 25-50. https://doi.org/10.1177/1466138113506632 
Howland, P. (2019). Enduring wine and the global middle class, in D. Inglis and A. Almila, (eds), The Globalization of Wine, (pp. 151-170). London: Bloomsbury. https:// doi.org/10.5040/9781474265027.ch-009

Inglis, D. (2019). Mutating and contested languages of wine: heard on the grapevine, in S. D. Brunn and R. Kehrein (eds), Handbook of the Changing World Language Map (pp. 4033-4058). Dordrecht: Springer. https://doi.org/ 10.1007/978-3-030-02438-3_205

Inglis, D. (2022). On divine wine: Wine gifts between gods and humankind, in P. Howland (ed), Wine and the Gift, London: Routledge.

Inglis, D. and Ho, H. K. (2022) Beyond white: On wine and ethnicity, in S. Charters, M. Demossier, J. Dutton, G. Harding, J. Smith Maguire, D. Marks and T. Unwin (eds), The Routledge Handbook of Wine and Culture. London: Routledge.

James, V. (2020). Wine Girl. London: Fleet.

Johnson, T. E. and Bastian, S. E. P. (2007). A preliminary study of the relationship between Australian wine consumers' wine expertise and their wine purchasing and consumption behaviour. Australian Journal of Grape and Wine Research, 13, 186-197. https://doi.org/10.1111/j.1755-0238.2007.tb00249.x

Kavanagh, D. (2016). New wine sparks sexism claims. Available at: https://www.wine-searcher.com/m/2016/02/ new-wine-sparks-sexism-claims (Accessed 18 February 2021).

Kennedy, T. M. (2017). Boxed wine feminisms: The rhetoric of women's wine drinking in The Good Wife, in M. A. Goldthwaite (ed), Food, Feminisms, Rhetorics (pp. 171-180). Carbondale: Southern Illinois University Press.

Killingsworth, B. (2006). 'Drinking stories' from a playgroup: Alcohol in the lives of middle-class mothers in Australia. Ethnography, 7(3), 357-384. https://doi.org/10.1177/1466138106067905

Koller, V. (2008). 'Not just a colour': Pink as a gender and sexuality marker in visual communication. Visual Communication, 7(4), 395-423. https:// doi.org/10.1177/1470357208096209

Langhamer, C. (2003). 'A public house is for all classes, men and women alike': Women, leisure and drink in second world war England. Women's History Review, 12(3), 423-443. https://doi.org/10.1080/09612020300200367

Lennox, J., Emslieb, C., Sweetinga, H. and Lyons, A. (2018). The role of alcohol in constructing gender \& class identities among young women in the age of social media. International Journal of Drug Policy, 58, 13-21. https://doi.org/10.1016/j.drugpo.2018.04.009

Lorey, T. (2021). The success of rosé wine in France: The millennial revolution. Cornell Hospitality Quarterly, 62(3), 357-370. https://doi.org/10.1177/1938965521993135

Ludington, C. (2013). The Politics of Wine in Britain: A New Cultural History. Basingstoke: Palgrave MacMillan. https://doi.org/10.1057/9780230306226

MacLean, N. (2007). Red, White, and Drunk All Over: A Wine-Soaked Journey from Grape to Glass. London: Bloomsbury.

Martin, A. L. (2001). Alcohol, Sex, and Gender in Late Medieval and Early Modern Europe. London: Palgrave Macmillan. https://doi.org/10.1057/9781403913937

Matasar, A. B. (2006). Women of Wine: The Rise of Women in the Global Wine Industry. Berkeley: University of California Press. https:// doi.org/10.1525/9780520930704

McClellan, M. L. (2017). Lady Lushes: Gender, Alcoholism, and Medicine in Modern America. New Brunswick: Rutgers University Press. https://doi.org/10.2307/j.ctt1pwtdn0

McCoy, E. (2020). A guide to top women winemakers, still rare in the world of grapes. Available at: https://www.bloombergquint.com/business/the-top-bottles-of-wine-produced-by-women (Accessed 1 July 2021).

McDonald, M. (1994). Introduction - A social-anthropological view on gender, drink and drugs, in M. McDonald (ed), Gender, Drink and Drugs (pp. 1-32). Oxford: Berg. https:// doi.org/10.4324/9781003135043-1

Mobley, E. (2020). Wine's diversity issue starts with the way we talk about the taste of wine. Available at: https://www.sfchronicle.com/wine/article/Wine-s-diversity-issue-starts-with-the-way-we-15544232.php (Accessed 4 September 2021).

Nicolson, P. (1990). Gender, power and wine selection: A pilot study. Journal of Wine Research, 1(3), 235-242. https://doi.org/10.1080/09571269008717880

Ody-Brasier, A. and Fernandez-Mateo, I. (2017). When being in the minority pays off: Relationships among sellers and price setting in the champagne industry. American Sociological Review, 82(1), 147-178. https://doi.org/10.1177/0003122416683394

Pariseau, L. (2021). The end of gendering wine. Available at: https:/ / punchdrink.com/articles/end-gendering-femininemasculine-wine-language/ (Accessed 15 November 2021).

Phillips, R. (2018). Wine: A Social and Cultural History of the Drink That Changed Our Lives. Oxford: Infinite Ideas.

Picard, D., Nascimento Moreira, C. and Loloum, T. (2018). Wine magic: Consumer culture, tourism, and terroir. Journal of Anthropological Research, 74(4), 526-540. https://doi.org/10.1086/699943 
Pietropaolo, C. (2016). Red, red wine: A family tradition, just not for women. Available at: http://www.theethnicaisle.com/new-blog-2/2016/2/23/you-cant-make-wine-when-youre-bleeding (Accessed 23 February 2021).

Pliny (1942). Natural History, Volume II: Books 3-7. Cambridge, MA: Harvard University Press.

Potter, S. (1952). One-Upmanship. London: Rupert Hart-Davis.

Price, P. V. (1990). Woman of Taste. London: John Murray.

Remedy Liquor (2018). Is wine good for women? 6 best girly wines. Available at: https:/ / remedyliquor.com/blog/is-winegood-for-women/ (Accessed 7 May 2021).

Remus, E. A. (2014). Tippling ladies and the making of consumer culture: Gender and public space in 'Fin-deSiècle' Chicago. The Journal of American History, 101(3), 751-777. https://doi.org/10.1093/jahist/jau650

Ritchie, C. (2009). The culture of wine buying in the UK off-trade. International Journal of Wine Business Research, 21(3), 194-211. https://doi.org/10.1108/17511060910985944

Robinson, J. (2017). The wine glass ceiling. Available at: https://www.jancisrobinson.com/articles/the-wine-glassceiling (Accessed 14 October 2021).

Rokka, J. (2017). Champagne: Marketplace icon. Consumption Markets \& Culture, 20(3), 275-283. https://doi.org/10.1080/10253866.2016.1177990

Ross, K. (2021). Wine press: 'License to drink' - Every cocktail, wine in every James Bond movie. Available at: https:/ /www.masslive.com/entertainment/2021/10/wine-press-licensed-to-drink-every-cocktail-wine-inevery-james-bond-movie.html (Accessed 4 October 2021).

Ross, R. (2014). Colour and sound proven to affect wine taste. Available at: https:/ /www.thedrinksbusiness.com/2014/ 06/colour-and-sound-proven-to-affect-wine-taste/ (Accessed 20 June 2021).

Saukko, P. and Reed, L. (2010). Governing the female body: Three dimensions of power, in P. Saukko and L. Reed (eds), Governing the Female Body: Gender, Health, and Networks of Power (pp. 1-16). Albany: Suny Press.

Shaw, L. (2020). In focus: The rosé revolution. Available at: https://www.thedrinksbusiness.com/2020/07/in-focusthe-rose-revolution/ (Accessed 22 July 2021).

Simmel, G. (2012). Selections from Simmel's writings for the journal Jugend. Theory, Culture \& Society, 29(7/8), 263278. https://doi.org/10.1177/0263276412457222

Skeggs, B. (2005). The making of class and gender through visualizing moral subject formation. Sociology, 39(5), 965-982. https://doi.org/10.1177/0038038505058381

Skerrett, P. J. (2012). Resveratrol - the hype continues. Available at: https://www.health.harvard.edu/blog/resveratrolthe-hype-continues-201202034189 (Accessed 3 February 2021).

Smith, G. W. H. (1989). Snapshots 'sub specie aeternitatis': Simmel, Goffman and formal sociology. Human Studies, 12, 19-57. https://doi.org/10.1007/BF00142838

Spence, C. (2015). Multisensory flavor perception. Cell, 161, 24-35. https://doi.org/10.1016/j.cell.2015.03.007

Spence, C. (2019). Problems associated with marketing food and drink specifically at women. Preprints 2019, 2019070034. https://doi.org/10.20944/preprints201907.0034.v1

Spence, C. and Levitan, C. A. (2021). Explaining crossmodal correspondences between colours and tastes. $i$ Perception, 12(3), 1-2. https:// doi.org/10.1177/20416695211018223

Spence, C. and Velasco, C. (2018). On the multiple effects of packaging colour on consumer behaviour and product experience in the 'food and beverage' and 'home and personal care' categories. Food Quality and Preference, 68, 226-237. https://doi.org/10.1016/j.foodqual.2018.03.008

Stewart, J. (2020). 'She shook her heavy tresses, and their perfume filled the place': The seductive fragrance of 'that awful sorceress': H. Rider Haggard's femme fatale, Ayesha. Gothic Studies, 22(3), 246-265. https:// doi.org/10.3366/gothic.2020.0060

Thach, L. (2012). Time for wine? Identifying differences in wine-drinking occasions for male and female wine consumers. Journal of Wine Research, 23(2), 134-154. https:/ / doi.org/10.1080/09571264.2012.676542

Velikova, N., Charters, S., Bouzdine-Chameeva, T., Fountain, J., Ritchie, C. and Dodd, T.H. (2015). Seriously pink: A cross-cultural examination of the perceived image of rosé wine. International Journal of Wine Business Research, 27(4), 281-298. https://doi.org/10.1108/IJWBR-10-2014-0050

Wilson, J. (2015). Brosé: Wine for the angsty bro who blushes when he 'drinks pink'. Available at: https://www.theguardian.com/commentisfree/2015/jul/29/brose-wine-for-the-angsty-bro-who-blusheswhen-he-drinks-pink (Accessed 29 July 2021).

Wine Tasting Bled (n.d.). Red wine for menstrual cramps? The best medicine you could ever have. Available at: https:/ / winetastingbled.com/red-wine-for-menstrual-cramps-the-best-medicine-you-can-ever-have/

Wyma, C. (2015). Make way for brosé: Why more men are drinking pink. Available at: https://www.gq.com/story/brosepink-wine-for-men (Accessed 3 June 2021)

Zhou, C. (2018). Equal, sometimes different. Available at: https://www.wineintelligence.com/equal-sometimesdifferent/ (Accessed 30 October 2021). 